\title{
Asset Management and Capital Ownership on Firm Value: Through Profitability
}

\section{Obi Banamtuan ${ }^{1}$, Diana Zuhroh², and Sihwahjoeni ${ }^{2}$}

${ }^{1}$ Graduate School University of Merdeka Malang

Jl. Terusan Raya Dieng No. 62-64 Malang, 65145, Indonesia

${ }^{2}$ Economic and Business University of Merdeka Malang

Jl. Terusan Raya Dieng No. 62-64 Malang, 65145, Indonesia

Info Artikel

Keywords:

Asset Management; Capital ownership; and Return On Investment.

ISSN (print) : 2598-7763 ISSN (online): 2598-7771

$\triangle$ Corresponding Author: Diana Zuhroh:

Tel. /Fax. +62 812-3314-833

E-mail: diana.zuhroh@unmer.ac.id (c)) EY-NC-SA

\begin{abstract}
Abtract
This study aims to analyze the effect of Asset Management (AM) and Good Corporate Governance (GCG) on stock prices through Return on Investments (ROI). This research is an explanation using quantitative methods. The population of 64 companies is listed on the Indonesia Stock Exchange and is engaged in property and construction. The sampling technique uses purposive sampling with the results of 36 companies. The data used is the 2016-2018 financial statements. The analysis used is path analysis. The results of the study prove that Management asset significantly influences ROI, GCG significantly influences ROI, Management asset significantly influences stock prices, GCG has a significant effect on stock prices, ROI has a significant effect on stock prices, Management asset has a significant effect on stock prices through ROI, GCG has a significant effect on share price through ROI.

Citation: Banamtuan, O., Zuhroh, D., and Sihwahjoeni. (2020). Asset Management and Capital Ownership On Firm Value: Through Profitability. AFRE Accounting and Financial Review, 3 (1)
\end{abstract}

\begin{abstract}
Abstraks
Penelitian ini bertujuan untuk menganalisis pengaruh pengelolaan aset dan Good Corporate Governance (GCG) terhadap harga saham melalui Return on Investmen (ROI). Penelitian yang dilakukan ini adalah explanatory dengan menggunakan metode kuanitatif. Populasi sebanyak 64 perusahaan yang terdaftar di Bursa Efek Indonesia dan yang bergerak di bidang properti dan konstruksi. Teknik sampling menggunakan purposive sampling dengan hasil sebanyak 36 perusahaan. Data yang digunakan adalah laporan keuangan tahun 2016-2018. Analisis yang digunakan adalah analisis jalur path. Hasil penelitian membuktikan bahwa pengelolaan aset berpengaruh signifikan terhadap ROI, GCG berpengaruh signifikan ROI, pengelolaan aset berpengaruh signifikan terhadap harga saham, GCG berpengaruh signifikan terhadap harga saham, ROI berpengaruh signifikan terhadap harga saham, pengelolaan aset berpengaruh signifikan terhadap harga saham melalui ROI, GCG berpengaruh signifikan terhadap harga saham melalui ROI.
\end{abstract}

JEL Classification: G11, G30, G32

DOI: https://doi.org/10.26905/afr.v3i1.4296

\section{INTRODUCTION}

Management will manage the company's assets to earn profits (Carstina, Siminica, Cîrci- umaru, \& Tănasie, 2015; Haryanto, 2016; Suhadak, Kurniaty, Handayani, \& Rahayu, 2019; and Le, 2019). Companies with higher profit levels show better company performance. Manage- 
ment will try to manage the company to provide value-added that is useful for all stakeholders. The implementation of good corporate governance will be able to improve company performance (Mashayekhi \& Mohammad, 2008; Bhagat \& Bolton, 2019, and Ciftci, Tatoglu, Wood, Demirbag, \& Zaim, 2019). GCG implementation is related to transparency, independence, accountability, responsibility, and fairness. Company management by referring to GCG principles can improve company performance and create a healthy business climate. Companies with good company performance are a positive signal for investors, so they can increase the level of investor confidence (Haryanto, 2014; Xu, Fernando, \& Tam, 2019; and Yulianto \& Widyasasi, 2020).

Utilization of assets to make a profit shows a good company performance in managing all the funds invested in assets. Company performance can be an attraction for investors (Brauer \& Zimmermann, 2019). Likewise, the implementation of GCG can provide accurate information for investors so that potential investors can put trust in the company by buying shares (Kaihatu, 2006; Mukhtaruddin, Ubaidillah, Dewi, Hakiki, \& Nopriyanto, 2019; and Sadiq \& Abbas, 2019). Corporate governance will ensure corporate investors do not invest funds in projects that are not profitable, and management will not embezzle funds. Investor confidence in the management of the company makes investors sure to invest their funds. This makes the demand for a stock will increase. The high demand for the purchase of stock prices, of course, will be followed by increasing stock prices (Brigham \& Houston, 2009: 70).

A rapidly changing business environment requires management to be able to manage its assets more carefully. Companies are required to be able to manage assets properly. The results showed that companies with good asset management are a positive signal for investors. Companies with good asset management are reflected in higher asset turnover productivity. Asset management will be related to how management allocates funds to assets that can increase sales. The results show that asset management affects firm value (Setyanto \& Permatasari, 2014; and Jariah, 2016). Asset management has an impact on the performance of the company (Khan, Tashfeen, \& Saghir, 2019). While researchers He and Xiong (2013); Putri, Rikumahu, \& Aminah (2018); and Diana \& Osesoga (2020) show that asset management does not affect firm value.

The company needs CGC implications so that the company can survive and be tough in facing increasingly fierce competition, and be able to apply business ethics consistently so that it can create a healthy, efficient and transparent business climate. The results of research related to GCG on financial performance and also on company value have been widely researched, but the results of the study show inconsistent results. The results of the study (Afrifa \& Tauringana, 2015; Bhagat \& Bolton, 2019; and Ciftci et al., 2019) showed that GCG affects company performance. While the research findings (Buachoom, 2018) show different results depending on company conditions.

This study aims to analyze the effect of asset management and Good Corporate Governance (GCG) on stock prices through Return on Investments (ROI) in companies engaged in property and construction, and those listed on the Indonesia Stock Exchange (IDX).

\section{HYPOTHESIS DEVELOPMENT}

\section{Effect of Asset Management on ROI}

Companies are required to be able to invest their funds properly. Companies that can manage assets well, then efficiency will tend to increase. A company with a high level of profitability indicates that the company can manage its assets well. Research finding Prempeh (2016) shows that raw material inventory management can have an impact on the profitability of manufacturing companies in Ghana. Finding research Haryanto et al., (2018); Khan et al., (2019) show that asset management has a positive effect on company performance. Based on the results of previous studies, the hypotheses of this study are:

$\mathrm{H}_{1}$ : Asset Management affects ROI

\section{Effect of GCG on ROI}

GCG implementation makes corporate governance carried out with better transparency and supervision. Management will invest funds in productive projects so that the company's profit will increase. Research by Gugler, et al (2004), Berger et al. (2005), Afrifa \& Tauringana (2015), Eksandy (2018), Gnawali (2018), Bhagat \& Bolton (2019) and Ciftci et al. (2019) shows that companies generate profit margins as an effect of the application of GCG in corporate institutions. Todorovic's research (2013) proves that there is a clear correlation and impact of the implementation of corporate governance principles on company performance. The research hypothesis can 
be formulated as follows:

$\mathrm{H}_{2}$ : GCG affects ROI

\section{Effect of Asset Management on Stock Prices}

Companies with good asset management demonstrate effective use of assets as well. The more effective management is managing assets, it will be able to improve company efficiency. The more efficient a company is, the higher its ability to make a profit. Coal (2017) concludes that asset management affects the market value of property companies listed on the IDX. Herninta and Tutik's research (2017) shows that asset management variables influence stock prices before being moderated by audit quality. Based on the results of previous studies, the hypotheses of this study are:

$\mathrm{H}_{3}$ : Asset Management affects stock prices.

\section{The Effect of GCG on Stock Prices}

The value of a company can be built and maintained through good corporate governance. Companies that are committed to implementing GCG consistently in managing the company will be able to increase investor confidence. Implementation of GCG will be able to reduce the risk of loss to the company, to increase investor confidence. The implementation of GCG will make investors confident that management will invest their funds in productive projects. Management will not only think short term but will also think about the sustainability and interests of all stakeholders. Research Mishra \& Mohanty (2014), Nisasmara, Holding, \& Orvernance (2016), Abdallah \& Ismail (2017), Mukhtaruddin et al., (2019) shows that GCG has a positive effect on firm value. Wida and Wayan's research (2014) concluded there was an influence of institutional ownership on firm value. Research Handayani, (2017), Mulyono et al (2018) proves that there is an influence of GCG on stock prices. Based on the results of previous studies, the hypotheses of this study are:

$\mathrm{H}_{4}$ : GCG affects the stock price

\section{Effect of ROI on Stock Prices}

The company's performance is a positive signal for investors. Companies with better performance indicate that the company is healthy and has good prospects. Good company performance reflects the company's strong fundamentals. Investors will be safer and more profitable investing in companies with good performance. Research companies (Chong \& Lopez-de-Silanes,
2006), Priatinah and Kusuma (2012), (Nisasmara et al., 2016) prove that ROI affects stock prices. Research Putra et al (2014) concluded that ROI has a significant effect on closing stock prices. Based on the results of previous studies, the hypotheses of this study are:

$\mathrm{H}_{5}$ : ROI affects the stock price

\section{Effect of Asset Management on stock prices through ROI}

Asset management is related to efficient asset management, especially current assets and fixed assets (Kasmir, 2009: 6), so that good utilization of assets can illustrate good company achievements in managing overall funds that can be measured by profitability (ROI) (Munawir, 2010: 89). Profitability ratios if they show well can provide an attraction for investors as investors to buy shares in the capital market (Brigham \& Houston, 2009: 70). The higher the interest of investors to invest their capital, the higher the demand to buy company shares, this will cause the stock price to rise as a result of high demand. Based on the explanation of the theory above, the hypothesis of this study is:

$\mathrm{H}_{6}$ : Asset management influences stock prices through ROI.

\section{The effect of GCG on stock prices through ROI}

The application of GCG can provide financial transparency, which can improve the quality of good financial statements, this has a good impact for investors, where potential investors as investors want to give confidence to the company by buying shares (Kaihatu, 2006). The higher the demand for the purchase of a share price, of course it will be followed by the increasing share price (Brigham \& Houston, 2009: 70). Based on the explanation of the theory above, the hypothesis of this study is:

$\mathrm{H}_{7}$ : GCG affects the stock price through ROI.

\section{DATA AND METHODS}

This research is an explanatory research using quantitative methods. In this study the financial statements of companies engaged in property and construction are listed on the Indonesia Stock Exchange (IDX), which are accessed online at http://www.idx.co.id. The population in this study were 64 property and construction companies listed on the IDX. The sampling technique used purposive sampling so that the samples in this study were 36 companies. Research variables 
and their measurements are presented in table 1.

Table 1. Variables and Measurements

\begin{tabular}{|c|c|}
\hline Variables and Concepts & Measurement \\
\hline Asset Management $\left(\mathrm{X}_{1}\right)$ & Income \\
\hline Is the company's assets turnover & Total Asset Turnover $=\overline{\text { Asset }}$ \\
\hline $\begin{array}{l}\text { Good Corporate Governance (X2) } \\
\text { GCG is measured using indicators of institutional } \\
\text { ownership. }\end{array}$ & $I C=\frac{\text { number of institutional shares }}{\text { Total Shares Outstanding }} \times 100 \%$ \\
\hline $\begin{array}{l}\text { Return On Investment (ROI) }\left(\mathrm{Y}_{1}\right) \\
\text { Is the company's ability to generate profits from assets }\end{array}$ & ROI $=\frac{\text { NetIncome After Tax }}{\text { Asset }} \times 100 \%$ \\
\hline $\begin{array}{l}\text { Stock Price }\left(\mathrm{Y}_{2}\right) \\
\text { The stock price variable is calculated using the } \\
\text { average price, and with the stock price return. }\end{array}$ & Return $=\frac{p_{t}-P t-1}{P t-1}$ \\
\hline
\end{tabular}

\section{RESULTS}

Based on the results of data analysis, it shows that the model (goodness fit of model) is significant. This can be seen from the significant value of 0.000 (Table 2). Based on the results of the $\mathrm{F}$ test shows that asset management and GCG have a significant effect on ROI. Asset management, GCG, and ROI variables affect stock prices.

Table 2. F Test (Simultaneous)

\begin{tabular}{llll}
\hline Variable & $F$ & $F_{\text {tablr }}$ & Sig F \\
\hline $\mathrm{X}_{1}$ and $\mathrm{X}_{2} \rightarrow \mathrm{Y}_{1}$ & 5.342 & \multirow{2}{*}{3.090} & 0.000 \\
$\mathrm{X}_{1}, \mathrm{X}_{2}$ and $\mathrm{Y}_{1} \rightarrow \mathrm{Y}_{2}$ & 9.747 & & 0.000 \\
\hline
\end{tabular}

Where: $\mathrm{X} 1$ = asset management, $\mathrm{X} 2=$ Good Corporate governance, $\mathrm{Y} 1=$ Return on Investment $(\mathrm{ROI})$ and $\mathrm{Y} 2=$ Stock price.

Partial test results are presented in Table 3. The results of the study show that asset management and GCG influence ROI. Asset management, GCG, and ROI affect stock prices (H1, H2, $\mathrm{H} 3, \mathrm{H} 4$, and H5, accepted)
The effect of asset management on stock prices through ROI, obtained a direct influence $\mathrm{X} 1$ on $Y 2$ of $(0.313)$, while the indirect effect of $X 1$ through $\mathrm{Y} 1$ on $\mathrm{Y} 2$ is $(0.563 \times 0.866=0.488)$, then the total effect given by $\mathrm{Y} 1$ to $\mathrm{Y} 2$ is $(0.313+0.488$ $=0.801$ ). Based on the calculation results it is known that the value of the direct effect of 0.313 is smaller than the indirect effect of 0.488 , this proves that asset management influences the stock price through $\mathrm{ROI}$, so that $\mathrm{H} 6$ is accepted.

The influence of GCG on stock prices through ROI, obtained a direct influence of X2 on $\mathrm{Y} 2$ of (0.332), while the indirect effect of $\mathrm{X} 2$ through $\mathrm{Y} 1$ on $\mathrm{Y} 2$ is $(0.545 \times 0.866=0.471)$, then the total effect given by $\mathrm{Y} 2$ to $\mathrm{Y} 2$ is $(0.332+0.471=$ 0.803 ). Based on the calculation results it is known that the value of the direct effect of 0.332 is smaller than the indirect effect of 0.471 , this proves that GCG affects the stock price through ROI, so that H7 is accepted.

Table 3. Analysis Results

\begin{tabular}{|c|c|c|c|c|}
\hline Variable & Beta & & $t_{\text {table }}$ & Sig $t$ \\
\hline $\mathrm{X}_{1} \rightarrow \mathrm{Y}_{1}$ & 0.563 & 3.877 & & $0.000^{*}$ \\
\hline $\mathrm{X}_{2} \rightarrow \mathrm{Y}_{1}$ & 0.545 & 2.860 & & $0.002 *$ \\
\hline $\mathrm{X}_{1} \rightarrow \mathrm{Y}_{2}$ & 0.313 & 2.596 & 1.980 & $0.007 *$ \\
\hline $\mathrm{X}_{1} \rightarrow \mathrm{Y}_{2}$ & 0.332 & 2.629 & & $0.005^{*}$ \\
\hline $\mathrm{Y}_{1} \rightarrow \mathrm{Y}_{2}$ & 0.866 & 5.237 & & $0.000^{*}$ \\
\hline $\mathrm{X}_{1} \rightarrow \mathrm{Y}_{1} \rightarrow \mathrm{Y}_{2}$ & \multicolumn{4}{|c|}{$0.563 \times 0.866=0.488(0.313<0.488)$} \\
\hline$X_{2} \rightarrow Y_{1} \rightarrow Y_{2}$ & \multicolumn{4}{|c|}{$0.545 \times 0.866=0.471(0.332<0.471)$} \\
\hline
\end{tabular}

Table 4. Coefficient of Determination $\left(\mathrm{R}^{2}\right)$

\begin{tabular}{lr}
\hline Model & $R$ Square \\
\hline $\mathrm{X}_{1}$ and $\mathrm{X}_{2} \rightarrow \mathrm{Y}_{1}$ & 0.684 \\
$\mathrm{X}_{1}, \mathrm{X}_{2}$ and $\mathrm{Y}_{1} \rightarrow \mathrm{Y}_{2}$ & 0.590 \\
\hline
\end{tabular}

The test results of the coefficient of determination $\left(R^{2}\right)$ are presented in table 4 . Based on Table 3 it can be seen that the results of the analy- sis of $R$ Square $\left(R^{2}\right)$, namely: $R^{2}$ value of variables $\mathrm{X} 1$ and $\mathrm{X} 2 \rightarrow \mathrm{Y} 1$ of 0.684 means that asset management (X1) and GCG (X2) are able to explain ROI (Y1) variant of $68.4 \%$. The $\mathrm{R}^{2}$ value of variables $\mathrm{X} 1, \mathrm{X} 2$, and $\mathrm{Y} 1 \rightarrow \mathrm{Y} 2$ is 0.590 , which means that asset management (X1), and GCG (X2) affect the stock price (Y2) through ROI (Y1) of $59.0 \%$. 


\section{Structural Equation Model Test}

Structural equation model to determine the coefficient of total determination (Rm2), with a view to knowing the overall effect of asset management and GCG variables on stock prices through ROI, the results of which are presented as follows:

$$
\begin{aligned}
& \mathrm{Rm}^{2}=1-\mathrm{Pe}^{2} \mathrm{Pe}_{2}{ }^{2} \ldots \ldots . . . \mathrm{Pe}^{2} \\
& \mathrm{P}_{\mathrm{e} 1}=\sqrt{1+\mathrm{R}^{2}}=\sqrt{1-0,684}=0,562 \\
& \mathrm{P}_{\mathrm{e} 2}=\sqrt{1+\mathrm{R}^{2}}=\sqrt{1-0,590}=0,640 \\
& \mathrm{Rm}^{2}=1-(0.562)^{2}(0.640)^{2} \\
& \mathrm{Rm}^{2}=1-(0.316)(0.410) \\
& \mathrm{Rm}^{2}=1-0.130 \\
& \mathrm{Rm}^{2}=0,870
\end{aligned}
$$

Based on the above calculation results obtained the coefficient of determination of the total effect of the variable asset management $(X 1)$ and GCG (X2) on stock prices (Y2) through ROI (Y1) of 0.870 , this shows the diversity of data that can be explained by the model is $87.0 \%$ or the information contained in $87.0 \%$ data can be explained by the model, while $13.0 \%$ is explained by other variables contained in the model (error).

\section{DISCUSSION}

\section{Effect of Asset Management on ROI}

The results showed that asset management had a positive and significant effect on ROI. Companies with good asset management, efficiency, and effectiveness in the use of assets will be even higher, so the company's profit will increase. These results indicate that good asset management can bring benefits to the company, thus impacting on improving the company's financial performance. The high ratio of earnings turnover to total assets can illustrate the value of the company, this is reinforced by the opinion of Tumewu (2014) that the higher the profitability obtained by the company, the better the company's performance.

The results of this study are in line with research by Yahaya et al (2015), Haryanto et al., (2018), and Khan et al., (2019) that asset management has a positive impact on financial performance. Research He and Xiong (2013) concluded that asset management is used as an investment strategy. Prempeh's research (2016) concluded that good asset management can increase company profitability.

\section{Effect of GCG on ROI}

Based on the results of the analysis it was found that GCG has a positive and significant effect on ROI. The results of this study illustrate that the high institutional ownership ratio of all outstanding shares of a company can create added value and provide confidence to all stakeholders that the company is safe when making investments. Arafat (2009: 12) states that the added value of GCG is the creation of transparency, independence, accountability, responsibility, and fairness so that it can improve good company performance as well.

The results of this study are in line with previous studies conducted by Gugler et al (2004), Afrifa \& Tauringana (2015), Benedicto (2015), Eksandy (2018), Gnawali (2018),(Bhagat \& Bolton (2019), and Ciftci et al., (2019), Almoneef \& Samontaray (2019), Al-Gamrh, Ku Ismail, Ahsan, \& Alquhaif (2020), and Wijaya \& Murhadi (2020) which concluded that the implementation of GCG in a company can produce profit margin. Todorvic's (2013) study, concluded that the application of GCG can have an impact on company performance.

\section{Effect of Asset Management on Stock Prices}

Based on the results of the analysis found that asset management has a positive and significant effect on stock prices. Asset management value measured using Total Assets Turnover obtained a high ratio value, this proves that asset turnover of assets is good, meaning that the company is able to manage its assets to gain profit so that it has an impact on increasing the value of the company in this case stock prices.

The results of this study are in line with the study of Coal (2017), Siddiqui \& Shoaib (2011), Mukhtaruddin et al., (2019) which concluded that asset management influences the company's market value. Another study conducted by Herninta and Tutik (2017) proved that asset management has an influence on stock prices. Thus it can be understood that the better the value of asset management is able to support an increase in stock prices.

\section{The Effect of GCG on Stock Prices}

Based on the results of the analysis found that positive GCG has a positive and significant effect on stock prices. These results indicate that the greater the GCG of a company, which is measured using the ratio of institutional ownership of shares outstanding, can provide confidence to investors to buy company shares and invest their capital. Public trust in a company is a positive va- 
lue that can have an impact on the high demand for company shares, so the share price will increase.

The results of this study are in line with previous research conducted by Kanpal and Kavidayal (2013), Mishra \& Mohanty (2014), Abdallah \& Ismail (2017), and Arayssi \& Jizi, (2019) which proves that good corporate governance has an influence on stock prices. Other studies conducted by Wida and Wayan (2014) prove that institutional ownership has an influence on firm value.

\section{Effect of ROI on Share Prices}

The results of the analysis in this study also found that a positive ROI affects the company's stock price. ROI which affects stock prices positively such as the increasing amount of net profit and company assets shows the company's performance in a healthy condition, this causes a good market response to the company's stock price. ROI can also be used as a management performance evaluation tool in achieving the effectiveness of a company. As explained by Kasmir (2013: 199) ROI as a measure of the effectiveness of mana-gement in managing its investments, so that if the ROI value is high it will affect investors' interest in investing in companies in Property \& Construction.

The results of this study are in line with research conducted by Priatinah and Kusuma (2012) which concluded that there is a positive influence on ROI on stock prices. Putra et al (2014), and Abdallah \& Ismail (2017) in their research concluded that ROI affects the closing price of shares. Another study conducted by Janitra and Kesuma (2015) concluded that ROI significantly affected stock returns.

\section{Effect of Asset Management on Share Prices through ROI}

Based on the results of the analysis found that positively the management of assets affects the stock price through ROI. Good asset management by maximizing all of its assets appropriately can increase revenue efficiently so that company goal are achieved. Companies that record profits every period can show financial performance in good condition. The value of the company's financial ratios that continues to increase every year is a positive value of the company that can give a signal to potential investors because the investor's goal is to invest to get the highest profit, so investors have an interest in investing by buying shares of companies that have highprofit ratios. The high demand for shares in the capital market, the price of shares offered will increase.

The researchers' findings above are supported by the study of Jordan et al (2012) in his research revealing that asset management shows efforts to ensure professional management so as to provide adequate information to investors. ElWassal (2013) in his research stated that asset management is carried out to ensure management professionalism in managing company assets as indicated by the company's performance in managing finances, this can have an impact on increasing corporate returns. Jayanti (2015) who in his research stated that the ability of a company's management in managing its assets to generate profits for the company plays an important role in improving the company's financial performance as measured using ROI.

\section{The Effect of GCG on Stock Prices through ROI}

Based on the results of the analysis it was found that GCG affects the stock price through ROI. The value of GCG in this study is measured using institutional ownership of the total outstanding shares, this can prevent agency conflicts because there is no management interest gap to commit fraud in seeking profits. The application of GCG can provide value added for companies for a long period of time, and can also increase competitiveness in the capital market. The increase in the company's added value will affect the stock price, this is because GCG can be used as a reference in carrying out the company's internal management, so that the output of financial performance will be seen from the level of profitability of the company, while also affecting the high stock price. The increase in share price itself occurs because the movement of demand in the capital market has increased, where market demand for shares outstanding has jumped, then the price of shares offered will also increase.

The results of this study are supported by Sarafina and Saifi (2017) research which proves that the implementation of good GCG affects the value of the company, this has an impact on the returns expected by shareholders, such as an increase in share value. Another supporting study was conducted by Syafitri et al (2018) who in their research results stated that the application of GCG can increase company value. 


\section{CONCLUSIONS AND SUGGESTIONS}

Based on the results of research and discussion that has been described, it can be concluded as follows that Asset Management and GCG have a significant effect on ROI. Asset management and GCG have a significant effect on stock prices. ROI has a significant effect on stock prices. Asset management influences stock prices through ROI and GCG affects stock prices through ROI.

Companies can pay attention to managing their assets as an effort to improve financial performance (profitability), and can also implement good corporate management by increasing institutional ownership to prevent agency conflicts within the company. Thus it can provide a positive signal for investors to invest their capital in the company.

The GCG indicators used in this study depend on institutional ownership. Further research can be added to other GCG indicators, such as independent committees and also managerial leadership.

\section{REFERENCE}

Abdallah, A. A. N., \& Ismail, A. K. (2017). Corporate governance practices, ownership structure, and corporate performance in the GCC countries. Journal of International Financial Markets, Institutions and Money, 46(November), 98-115. https://doi.org/10.1016/j.intfin.2016.08.004

Afrifa, G. A., \& Tauringana, V. (2015). Corporate governance and performance of UK listed small and medium enterprises. Corporate Governance (Bingley), 15(5), 719-733. https://doi.org/10.1108/CG-03-2015-0029

Al-Gamrh, B., Ku Ismail, K. N. I., Ahsan, T., \& Alquhaif, A. (2020). Investment opportunities, corporate governance quality, and firm performance in the UAE. Journal of Accounting in Emerging Economies, 10(2), 261276. https://doi.org/10.1108/JAEE-12-20180134

Almoneef, A., \& Samontaray, D. P. (2019). Corporate governance and firm performance in the Saudi banking industry. Banks and Bank Systems, 14(1), 147-158. https://doi.org/10.21511/bbs.14(1).2019.13

Arafat, Wilson. (2008). How to Implement GCG Effectively. Jakata: Skyrocketing Publisher

Arayssi, M., \& Jizi, M. I. (2019). Does corporate governance spillover firm performance? A study of valuation of MENA companies. Social Responsibility Journal, 15(5), 597-620. https://doi.org/10.1108/SRJ-06-2018-0157

Batubara, S.M. (2017). Identifikasi Manajemen Aset dan Kinerja Keuangan terhadap nilai Pasar pada Perusahaan Properti yang Terdaftar di Bursa Efek Indonesia. Jurnal Manajemen MOTIVASI. 13(1), 807-814.

Benedicto, F. (2015). The Corporate Governance and Firm Performance: A Review of Existing Empirical Evidence. European Journal of Business and Management, 7(33), 92 98.

Berger, A. N., Clarke, G. R. G., Cull, R., Udell, G. F., Klapper, L., \& Udell, G. F. (2005). Corporate governance and bank performance: A joint analysis of the static, selection, and dynamic effects of domestic, foreign, and state ownership. Journal of Banking and Finance, 29(8-9 SPEC. ISS.), 2179-2221.

https://doi.org/10.1016/j.jbankfin.2005.03.0 13

Bhagat, S., \& Bolton, B. (2019). Corporate governance and firm performance: The sequel. Journal of Corporate Finance, 58 (March), 142-168. https://doi.org/ 10.1016/j.jcorpfin.2019.04.006

Brauer, M., \& Zimmermann, M. (2019). Investor Response to Workforce Downsizing: The Influence of Industry Waves, Macroeconomic Outlook, and Firm Performance. Journal of Management, 45(5), 1775-1801. https://doi.org/10.1177/0149206317734901

Brigham, Eugene F., dan Joel F. Houtson. (2009). Fundamental of Financial Management, 12th Edition. Mason: South-Western Cengage Leaning.

Buachoom, W. (2018). How Do Board Structures of Thai Firms Influence on Different Quantile Levels of Firm Performance? 157-189. https://doi.org/10.1108/s2514465020180000006004

Carstina, S., Siminica, M., Cîrciumaru, D., \& Tănasie, A. (2015). Correlation Analysis of the Indicators of Asset Management and Profitability. III(2), 3-21.

Chong, A., \& Lopez-de-Silanes, F. (2006). Corporate Governance and Firm Value in Mexico. Working Paper, Inter-American Development Bank, 564(July).

Ciftci, I., Tatoglu, E., Wood, G., Demirbag, M., \& Zaim, S. (2019). Corporate governance and 
firm performance in emerging markets: Evidence from Turkey. International Business Review, 28(1), 90-103. https://doi.org/ 10.1016/j.ibusrev.2018.08.004

Diana, L., \& Osesoga, M. S. (2020). Pengaruh likuiditas, solvabilitas, manajemen aset, dan ukuran perusahaan terhadap kinerja keuangan. Jurnal Akuntansi Kontemporer, 12(1), 20-34. https://doi.org/10.33508/ jako.v12i1.2282

Eksandy, A. (2018). Pengaruh Good Corporate Governance Terhadap Kinerja Keuangan Pada Perbankan Syari'Ah Indonesia. Jurnal Akuntansi: Kajian Ilmiah Akuntansi (JAK), 5(1), $\quad$ 1. https://doi.org/10.30656/ jak.v5i1.498

Gnawali, A. (2018). Corporate Governance and Its Impact on Financial Performance in Nepalese Commercial Banks. International Journal of Modern Research in Engineering $\mathcal{E}$ Management, 1(7), 41-51.

Gugler, Klaus, Mueller Dennis C., and Yurtoglu B. Burcin. (2004). Corporate Governance and The Returns on Investmen. The Journal of Law E Economics. 47(2), 589-633

Handayani, B. D. (2017). Mekanisme Corporate Governanc, Enterprise Risk Management, dan Nilai Perusahaan Perbankan. Jurnal Keuangan Dan Perbankan, 21(1), 70-81.

Haryanto, S. (2014). Identifikasi Ekspektasi Investor melalui Kebijakan Struktur Modal, Profitabilitas, Ukuran Perusahaan dan GCPI. Jurnal Dinamika Manajemen. Jurnal Dinamika Manajemen, 5(2), 183-199. https://doi.org/10.15294/jdm.v5i2.3660

Haryanto, S. (2016). Profitability Identification of National Banking Through Credit, Capital, Capital Structure, Efficiency, and Risk Level. Jumal Dinamika Manajemen (JDM), 7(1), 11-21.

Haryanto, S., Rahadian, N., Fatima, M., Mbapa, I., Nesty, E., \& Vivi, K. (2018). Kebijakan Hutang , Ukuran Perusahaan dan Kinerja Keuangan Terhadap Nilai Perusahaan: Industri Perbankan di Indonesia. 1(2), 62-70.

Herninta, Tiwi., dan Tutik, Hesti Puspaya. (2017). Pengaruh Profitabilitas, Leverge, Kebijakan Dividen, Likuiditas dan Manajemen Aset terhadap Harga Saham yang Dimoderasi oleh Kualitas Audit (Sektor Properti, Real Estate dan Konstruksi di BEI Periode 20112015). ESENSI, 20 (1), 71-95.

He, Zhiquo., and Xiong, Wei. (2013). Delegated Asset Management, Investmen Mandates, and Capital Immobility. Journal of Financial Economics, 107, 239-258.

Janitra, Putu Vito Veda., dan Kesuma I Kwtut Wijaya. (2015). Pengaruh EPS, ROI dan EVA terhadap Return Saham erusahaan Otomotif di BEI. E-Jurnal Manaemen Unud,.4, (7), 18311844.

Jariah, A. (2016). Likuiditas, Leverage, Profitabilitas Pengaruhnya Terhadap Nilai Perusahaan Manufaktur Di Indonesia Melalui Kebijakan Deviden. Riset Akuntansi Dan Keuangan Indonesia, 1(2), 108-118.

Jayanti, E. D. 2015. Pengaruh Return On Investment (ROI), Earning Per Share (EPS), dan Price Earning Ratio (PER) terhadap Harga Saham Perusahaan Pertambangan yang Terdaftar di BEI Tahun 2011-2013. Artikel Ilmiah, Sekolah Tinggi Ilmu Ekonomi Perbanas Surabaya

Jordan, Brandfod D., Liu, Mark H., Wu, Qun. (2012). Do Investment Bank Listen to Their Own Analysts. Journal of Banking \& Financial, 36(5), 1452-1463.

Kaihatu, T. S. (2006). Good corporate governance dan penerapannya di indonesia. Jurnal Manajemen Dan Kewirausahaan, 8(1), 1. https://doi.org/10.9744/jmk.8.1.pp. 1-9

Kandpal, V., dan Kavidayal P.C. (2013). Effects Corporate Governance on Share Prices of BSE 200 Indeks Listed Companies in India. Conference: IFC organized by IIM Ahmedabad, IIM Calcutta and IIM Bangalore, At IIM Ahmedabad

Kasmir. (2009). Pengantar Manajemen Keuangan. Jakarta: Kencana, Prenada Media Grup.

Kasmir. (2013). Analisis Laporan Keuangan. Raja Grafindo Persada, Jakarta

Khan, M. M. S., Tashfeen, R., \& Saghir, S. (2019). Working capital management and performance in manufacturing sector of Pakistan. Journal of Business $\mathcal{E}$ Retail Management Research, 13(03), 70-82. https://doi.org/10.24052/jbrmr/v13is03/ar $\mathrm{t}-07$

Le, B. (2019). Working capital management and firm' $s$ valuation, profitability and risk Evidence from a developing market. 15(2), 191-204. https://doi.org/10.1108/IJMF-01-2018-0012

Mashayekhi, B., \& Mohammad, S. B. (2008). Corporate Governance and Firm Performance in Iran. 4(2), 156-172. https://doi.org/ 10.1016/S1815-5669(10)70033-3

Mishra, S., \& Mohanty, P. (2014). Corporate governance as a value driver for firm 
performance: Evidence from India. Corporate Governance (Bingley), 14(2), 265-280. https://doi.org/10.1108/CG-12-2012-0089

Mukhtaruddin, M., Ubaidillah, U., Dewi, K., Hakiki, A., \& Nopriyanto, N. (2019). Good Corporate Governance, Corporate Social Responsibility, Firm Value, and Financial Performance as Moderating Variable. Indonesian Journal of Sustainability Accounting and Management, 3(1), 55. https://doi.org/10.28992/ijsam.v3i1.74

Munawir. (2010). Analisis Laporan keuangan. Edisi Keempat. Yogyakarta: Liberty.

Mulyono., Suprapto, Tteguh. A, dan Prihandoko, Danang. (2018). The Effect of Corporate Governance and Firm Performance on Stock Price An Empirical Study on Indonesia Stock Exchange. Binus Business Review, 9 (1), 79-85.

Nisasmara, P. W., Holding, C., \& Orvernance, G. C. (2016). Cash Holding, Good Corporate Governance and Firm Value. 7(36), 117-128.

Prempeh, Kwadwo Boateng. (2016). The Impact of Efficient Inventory Management on Profitability: Evidence From Selected Manufakturing Firms in Ghana. International Journal of Financial and Accounting, Vol.5 (1), 22-26.

Priatinah, D., dan Kusuma, P.A. (2012). Pengaruh Return on Investmen (ROI), Earning Per Share (EPS), dan Dividen Pers Share (DPS) terhadap Harga Saham Perusahaan Pertambangan yang Terdaftar di Bursa Efek Indonesia (BEI) Periode 2008-2010. Jurnal Nominal, 1 (1), 50-64.

Putra, Y.P., Dzulkirom M.A.R., Rahayu, S.M. (2014). Pengaruh Return on Investmen, Return on Equity, Net Profit Margin, dan Earning Per Share terhadap Harga Penutupan Saham Perusahaan (Studi pada Perusahaan Properti dan Real Estate yang Terdaftar di BEI Periode 2010-2012). Jurnal Administrasi Bisnis (JAB), 8 (2), 1-7.

Putri, F. K., Rikumahu, B., \& Aminah, W. (2018). Kebijakan Hutang, Profitablitas, Dan Manajemen Aset Terhadap Nilai Perusahaan. Jurnal Riset Akuntansi Kontemporer, 10(2), 80-89.

Sadiq, M., \& Abbas, M. (2019). Does corporate governance play any role in investor confidence, corporate investment decisions relationship? Evidence from Pakistan and India. Journal of Economics and Business, 105(March), 105839. https://doi.org/10.1016/j.jeconbus.2019.03.
003

Sarafina, S., dan Saifi, M. (2017). Pengaruh Good Corporate Governance terhadap Kinerja Keuangan dan Nilai Perusahaan (Studi pada Badan Usaha Milik Negara (BUMN) yang Terdaftar di Bursa Efek Indonesia Periode 2012-2015). Jurnal Administrasi Bisnis (JAB), 50, (3), 108-117.

Syafitri, T., Nuzula, N.F., dan Ferina, N.. (2018). Penaruh Good Corporate Governance terhadap Nilai Perusahaan (Studi Pada Perusahaan Industri Sub Sektor Logam dan Seenis yang Terdaftar di BEI Periode 20122016). Jurnal Administrasi Bisnis (JAB), 56 (1), 118-126.

Setyanto, A. D., \& Permatasari, I. (2014). Manajemen Modal Kerja Dan Dampaknya Terhadap Nilai Perusahaan Dengan Corporate Governance Sebagai Variabel Pemoderasi. Akrual Jurnal Akuntansi, 6(1), 66-82.

Siddiqui, M. A., \& Shoaib, A. (2011). Measuring performance through capital structure: Evidence from banking sector of Pakistan. African Journal of Business Management, 5(5), 1871-1879. https://doi.org/10.5897/AJBM10.976

Suhadak, S., Kurniaty, K., Handayani, S. R., \& Rahayu, S. M. (2019). Stock return and financial performance as moderation variable in influence of good corporate governance towards corporate value. Asian Journal of Accounting Research, 4(1), 18-34. https://doi.org/10.1108/ajar-07-2018-0021

Todorovic, I. (2013). Impact of Corporate Governance on Performance of Companies. Montenegrin Journal of Economics, 9. (2), 47-53.

Tumewu, R.C. (2014). Pengaruh Penerapan Good Corporate Governance terhadap Profitabilitas pada Perusahaan Perbankan yang Terdaftar di BEI Periode 2009-2013. Artikel Program Pendidikan Profesi Akuntansi, Fakultas Ekonomi dan Bisnis, universitas Sam Ratulangi Manado.

Wida, P.D. Ni Putu., dan Suartana I W. (2014). Pengaruh Kepemilikan Manajerial da Kepemilikan Insttusional pada Nilai Perusahaan. E-Jurnal Akuntans Universias Udayana, 9 (3), 575-590.

Wijaya, L., \& Murhadi, W. (2020). Corporate governance structure and firm performance in the indonesian capital market. Advances in Economics, Business and Management Research, 115. 
Xu, Q., Fernando, G. D., \& Tam, K. (2019). Advances in Accounting Trust and fi rm performance: A bi-directional study. Advances in Accounting, 100433. https://doi.org/10.1016/j.adiac.2019.100433

Yahaya, O.A., Kutingi, U.M., Solanke, Abiola A., Onyabe, Joseph M., and Osman, S.O. (2015). Current Assets Management and Financial Performance: Evidance from Listed Deposit Money Bank in Nigeria. International Journal of African and Asia Studies, 13, 45-57.

Yulianto, \& Widyasasi. (2020). Analisis FaktorFaktor Yang Mempengaruhi Nilai Perusahaan. Jurnal Paradigma Akuntansi, 2(2), 576-585. 